\title{
Noget om Myterne omkring \\ den Clausen'ske injuriesag og \\ Grundtvigs censurperiodes afslutning
}

\section{Af Poul Dam}

Ingen, der skriver om Grundtvig, kan begynde helt forfra på alle felter. Man bør selvsagt vide, hvad forgængerne har skrevet, og man kan til en vis grad støtte sig til det, man kan læse hos gode forfattere. Noget bliver nødvendigvis gentagelser, og det behøver ikke at være af det onde. På den anden side: såfremt der er indløbet misforståelser undervejs, risikerer man, at disse konserveres, og det er faktisk sket en gang imellem.

I nogle tilfælde har misforståelsernes ophav været et alt for nidkært forsvar for Grundtvig. Somme har taget hans parti i en grad og med et ordvalg, som han selv nok ville have betragtet med et stille smil - eller måske en homerisk latter. Nogle af de myter, der har dannet sig i tidens løb, står dårligt til hans notoriske - men ikke af alle grundtvigianere erkendte eller påsk ønnede - selvironi.

Selv de bedste forfattere er undertiden blevet ofre for en upålidelig traditions mytedannelser. For eksempel skriver K.E.Bugge således i sin artikel om Grundtvig i den seneste udgave af Dansk Biografisk Leksikon:

1)

2)

3)

»Clausen anlagde injuriesag mod G. og vandt processen idet G. i 1826 blev $d \phi m t$ til livsvarig censur.« »Umiddelbart efter injuriedommen nedlagde G. påny sit embede.«

"Som følge af en lempelse af de gældende bestemmelser løstes G. i 1837 fra censuren, $i$ hvilken anledning han skrev sin velkendte sang til modersmålets pris »Moders navn er en himmelsk lyd «.«

(Fremhævelserne her og i andre citater er mine.)

Alle tre påstande findes også hos en række andre forfattere, (f.eks i Chr. Thodbergs Grundtvig-artikel i Den Store Danske Encyklopaedi: „Grundtvig blev året efter id $\phi m t$ livsvarig censur «) og der er ingen grund til at bebrejde Bugge, at han har troet på dem. De er faktisk så udbredte, at man bliver mødt med mistro, når man sætter spørgsmålstegn ved dem. 
F.eks. ved den sidste om baggrunden for »Moders navn«. I noterne til højskolesangbogens syttende udgave måtte jeg derfor lade mig nøje med at skrive: »Skrevet julenat 1837, efter traditionen i glæde over, at censuren over Grundtvig var ophævet. «Jeg tror imidlertid ikke på denne tradition, som jeg ikke har kunnet spore ophavet til - selv om det ikke ville undre mig, hvis den stammede fra Holger Begtrup. Første gang, noget $\mathrm{i}$ denne retning blev antydet $\mathrm{i}$ højskolesangbogens noter, var i ellevte udgave fra 1926, hvori Ejnar Skovrup havde revideret Nutzhorns noter, men han skrev blot: »Skrevet i julen 1837, da censuren over Gr. blev hævet.« Altså en notering af samtidighed, ikke en udtrykkelig påstand om årsagssammenhæng.

Sådan som den stærkt forkortede sang synges i dag, kan den nok anvendes som en hyldest til modersmålet, men hvis man vil spørge om tankerne bag digtet, er det selvsagt mere rimeligt at se på dette i dets helhed, og så kan man ikke undgå at se, at det handler om mere og egentlig om andet. Det er ikke sproget som sådan, men sproget $\mathrm{i}$ pigemunde, som Grundtvig besynger:

Længe leve i Danevang

Smaapigernes Maal det søde!

Op det stande i Pigesang,

Hvad godt der i Danmark døde,

Sødt i Lyst og sødt i Nød,

Sødt i Liv og sødt i Død,

Sødt i Eftermælet!

Og i en anden strofe, som kun Frederik Lange Grundtvig har brugt i en sangbog:

Bort da flyve med Vildgjæs graa,

Hvad Mund har fra Moder stjaalet!

Synger for os, I Piger smaa!

Saa prise vi Modersmaalet,

Sødt i Lyst og sødt i Nød,

Sødt i Liv og sødt i Død,

Sødt i Eftermælet!

At denne pointe, som der lægges op til gennem hele digtet, men helt utvetydigt fra den ottende af de i alt tyve strofer, er gået i glemmebogen, 
skyldes vel ikke mindst højskoleverdenens patriarkalisme. Grundtvigs positive holdning til den ene halvdel af himlen passede ikke rigtigt til de første højskolefolks mandsverden.

Når man læser hele digtet, er det svært at fatte, hvordan nogen kan have sat det i forbindelse med censurens ophævelse. Der er ikke noget i det, som kan tolkes aktuelt - intet, der peger på et bestemt tilblivelsestidspunkt. Det er heller ikke lykkedes mig at finde eksterne vidnesbyrd i den retning. De tidligste biografier - Bruns og Rønnings har intet om digtets eventuelle sammenhæng med censurens bortfald, der står ikke noget i Poetiske Skrifter (bind 6, side 186), og så vidt jeg kan se er der heller ikke noget i samtidige breve, der peger i denne retning. Måske er myten opstået på grund af det forhold, at digtet - hvornår det end er skrevet - blev trykt som indledning til Skolen for Livet, der udkom i februar 1838 som det første selvstændige skrift, Grundtvig kunne udsende uden det forhadte »Maa trykkes «, men dette forekommer mig at være en noget tyndbenet forklaring. At Steen Johansen accepterede overleveringen (se slutningen af bibliografiens nr. 580) er interessant nok, men - usædvanligt for Johansen - der savnes enhver henvisning til nogen form for dokumentation. Traditionen om julenat $1837 \mathrm{~b} \emptyset \mathrm{r}$ nok også forkastes.

Censurens ophævelse var for øvrigt ikke en så påfaldende nådesakt, som mange forfattere (ikke Bugge!) synes at have ment. Ved plakat af 1. november 1837 var trykkefrihedsforordningens regel om, at enhver domfældelse automatisk medførte livsvarig censur, blevet ændret til en bestemmelse om, at censur skulle idømmes på et vist åremål - først ved tredje dom kunne den gøres livsvarig. Grundtvig havde derfor god juridisk baggrund for at bede om fritagelse for censuren, således som han gjorde det $\mathrm{i}$ den henvendelse til kongen, der (som koncept) er gengivet i Breve fra og til N.F.S. Grundtvig (nr. 402). Men dertil kommer, at Frederik den Sjette, der altid havde haft en svaghed for Grundtvig, nu havde fået en mulighed for at hjælpe ham uden at underkende domstolens afgørelse.

Skal man bygge på konceptet, var henvendelsen således:

»Allernaadigste Konge Majestæten har i et allernaadigst Tillæg til Trykke-Anordningen overordentlig formildet de tidligere Bestemmelser, saa Censurens Varighed herefter skal beroe paa Forseelsens Grad og første Gang kun tilkiendes i det Høiste paa 
5 Aar, og Dette giver mig Mod til allerunderdanigst at bede mig fritaget for den Censur, jeg nu i fulde 10 Aar har været under!

Med den Retning, min Pen altid har havt, kan det maaskee vel synes, som Censuren maatte være mig ligegyldig, men deels er det mig netop derfor en Pine at giælde for en mistænkelig Skribent, og desuden er de formelle Bestemmelser ved Politi-Censuren saa byrdefulde, at det, uden vedkommende Embedsmænds Gunst vilde været mig aldeles umueligt at fortsætte den literære Virksomhed, som Majestæten i en lang Række af Aar allernaadigst har opmuntret og understøttet. Paa disse Grunde beder jeg, at den Censur, hvorunder jeg, efter en Hof og Stadsrets Dom i en Privat-Sag 1827 (sic!) faldt, allernaadigst maatte hæves. ${ }^{1}$

Denne skrivelse kan selvfølgelig ikke uden videre tages som fuldgyldigt udtryk for Grundtvigs mening om den censur, han havde været undergivet. Skrivelsen havde et formål, og hvis dette skulle opnås, var det vigtigt at belægge ordene rigtigt. Men det er alligevel interessant, at Grundtvig fremhævede, at de pågældende embedsmænd havde været ham gunstige, og at censuren kunne synes at være ham ligegyldig. Han havde tilsyneladende ingen vanskeligheder med at få politiets "Maa trykkes«. Den eneste tekst, der ikke fik lov at fremkomme - den tredje del af afhandlingen Religions-Frihed - var faktisk blevet godkendt af censuren - og trykt -, men blev så beslaglagt af politiet. Den var for øvrigt også på kanten af det, som Grundtvig kunne tro ville blive accepteret -.den handlede nemlig i høj grad om den Clausen'ske sag altså om selve baggrunden for den dom, som medførte censur. Måske var der tale om en prøveballon fra Grundtvigs side. Den eneste gang, der herudover havde været problemer, var ved udsendelsen af skriftet Til Nordmaend om en norsk H $\phi i$-Skole. Det var blevet trykt i Christiania, men en del eksemplarer kom til København og kunne købes her. Det havde censurreglerne ikke taget højde for. Ellers gik det nemt nok og efter alt at dømme også ganske hurtigt med at få censurens godkendelse af Grundtvigs arbejder. Men »Pinen « ved at »giælde for en mistænkelig Skribent « var reel nok, og det må bestemt virke sært på vor tid, at SangVark til den danske Kirke - med Poul Borums ord »en af de betydeligste, om ikke den betydeligste digtsamling på dansk « - kun kunne udkomme med censor Reiersens godkendelse! 
Mon ikke Reiersen, der skal have været en langt mere venlig og rimelig person, end Corsarens samtidige forhånelse af ham (d.v.s. af hans embede) giver indtryk af, har draget et lettelsens suk, da han ikke længere behøvede at gennemlæse Grundtvigs skrifter, der nok lå ham ret fjernt, men i stedet kunne koncentrere sig om aviser og den slags.

Grundtvig havde altså været under censur i elleve år. Det er imidlertid en misforståelse, at han var blevet idømt livsvarig censur. Denne var som antydet ifølge trykkefrihedsforordningen af 1799 § 20 en automatisk følge af enhver dom for overtrædelse af forordningen ganske uden hensyn til brødens alvor og omfang. Årsagen til, at denne foranstaltning var blevet en del af 1799-forordningen, kendes vist ikke, men man kan tænke sig, at formålet var sanitært - man kunne gennem censuren forhindre, at folk, der havde forbrudt sig, påny gav anledning til sager ved domstolene. Man $\emptyset$ nskede nok at forebygge retssager. Formynderisk, men måske velment - selv om grundlovens udtryk »censur og andre forebyggende foranstaltninger « nok skal ses på denne baggrund - og vistnok skyldes den ivrige grundtvigianer Frederik Barfod. (Oversigten over trykkefrihedssager i Harald Jørgensens disputats Trykkefrihedsspørgsmaalet i Danmark 1799-1848, København 1944, viser, at det ikke var uden grund, at man frygtede et stort antal mere eller mindre tåbelige sager, der blev rejst af - eller mod - diverse kværulanter. De virkelige frihedsinteresser, der må knyttes til navne som Goldschmidt, Ploug og Lehmann (samt altså Grundtvig), optræder mere sjældent i materialet.)

Det var slet ikke injuriedommen som sådan, der fik Grundtvig til at søge sin afsked fra embedet ved Vor Frelsers kirke. Den faldt nemlig først et halvt år efter, at han var fratrådt. Forklaringerne på, hvad der lå bag, er skiftende og delvis uklare - også Grundtvigs egne - men der skete i hvert fald to ting i april-maj 1826, som kan have virket sammen: Dels fik Grundtvig forbud mod at lade sine egne salmer (heriblandt Den signede Dag) afsynge ved den danske kirkes 1000 årsfest, dels havde retten, der behandlede Clausens injuriesag, i en kendelse udtalt sig imod Grundtvigs nedlagte påstand om, at sagen burde afvises. Sagen måtte herefter gå sin gang, og når den med tiden blev optaget til dom, ville Grundtvig nok blive dømt, og uanset hvor mild dommen var, måtte den så - i overensstemmelse med lovens regler - medføre livsvarig censur. 
Da denne kendelse få uger efter blev ledsaget af stiftsprovstens anatema mod Grundtvigs salmer, (og det kan ikke glemmes, at stiftsprovsten var H.N.Clausens far), er det psykologisk betragtet ikke uforståeligt, at Grundtvig gav op, men måske bør man tage endnu flere forhold i betragtning.

Rønning peger i sin Grundtvigbiografi (bind III, 1, side 147) på tre grunde, som han finder belagt i samtidige breve:

1) $\quad$ Urenheden« i den danske statskirke,

2) den omstændighed, at han, når han i henhold til sin embedsed bestred vantroen, kunde være udsat for injurie-processer, og

3) den personlige ejendommelighed, at han »kun var skikket til prædikant, ej til det daglige hyrdeliv«.

Det sidste kan ikke have været noget nyt for ham, men må til en vis grad have været en plage et stykke tid, og biskop Münters udtalelse (formentlig $\mathrm{i}$ en påtegning på Grundtvigs ad embedsvejen fremsendte klage til kancelliet over at være blevet indstævnet for sin embedsførelse, jf. Rønnings anf. skr. side 129) om, at Grundtvigs angreb på ingen måde kunne anses som et led $\mathrm{i}$ hans embedsf $\varnothing$ relse - »hans Embede er at være Præst paa Kristianshavn « - kan ikke have opmuntret ham - at blive henvist alene til det, som han med sig selv følte, at han havde mindst anlæg for, må have virket som en spand koldt vand.

Hvorom alting er, rettens kendelse om, at sagen skulle have sin gang, kan kun have været en årsag blandt flere.

Denne kendelse er imidlertid ganske interessant, og fordi hverken denne eller den endelige dom synes optrykt siden 1827, da de to aktstykker blev udgivet af J. Roed i et lille hæfte, aftrykkes de i det følgende, således som de fremkom den gang. ${ }^{2}$

Udskrift af Kjendelse-Protocollen i den kongelige Lands-Overret samt Hof-og Stads-Ret i Kjøbenhavn.

Aar 1826 den 10de April blev i Sagen:

Doctor philosophiæ Hr. Henrich Nicolai Clausen, Professor extraordinarius i Theologien ved Kjøbenhavns Universitet contra: 
Residerende Capellan ved Vor Frelsers Kirke paa Christianshavn, Hr. Nicolai Frederik Severin Grundtvig afsagt følgende:

Kjendelse:

Da Afgjørelsen af det Spørgsmaal, om de Beskyldninger, hvilke Indstævnte, residerende Capellan ved Vor Frelsers Kirke paa Christianshavn Hr. Nicolai Frederik Severin Grundtvig, har fremført mod Citanten Doctor Philosophiæ Hr. Henrich Nicolai Clausen, Professor extraordinarius i Theologien ved Kjøbenhavns Universitet i det under nærværende Sag omhandlede Skrift: »Kirkens Gjenmæle mod Professor theologiæ Dr. H.N. Clausen « kaldet, maatte indeholde noget Brud paa Citantens Ærerettigheder, eller blot opløse sig i en Strid om religieuse Meninger, saavelsom af den Qvæstion: om og hvorvidt det, saafremt det antages, at de paatalte Beskyldninger ere krænkende for Citantens Ære, maatte være nødvendigt eller lovligt, i at bedømme deres Værd, at tage Hensyn til den af Citanten i sit Skrift, kaldet »Catholicismens og Protestantismens Kirkeforfatning, Lære og Ritus « foredragne Lærdoms Beskaffenhed, Ægthed eller Falskhed, og endelig Fastsættelsen af de yderligere Følger, hvortil disse Spørgsmaales Besvarelse maatte lede, henhøre under Sagens Realitet, vil de 2de første Grunde, hvorpaa Indstævnte har paastaaet nærværende Sag afviist, nemlig: 1), at de i Skriftet »Kirkens Gjenmæle o.s.v.« mod Citanten gjorte Beskyldninger ikke angaae noget i dennes borgerlige Vandel, der ved Domstolene kan sættes i fuldkommen klart Lys, hvorved Indstævnte, efter den Udvikling, han har gjort af denne Paastand, maa antages at have forstaaet, at de ikke indeholde noget Angreb paa Citantens almindelige eller specielle borgerlige Agtelse, og saaledes ikke qvalificerede sig til et Injuriesøgsmaal, og 2), at Domstolene skulde være uberettigede til, efter en privat Mands Forlangende, at drøfte en Strid om religieuse Gjenstande paa den eneste Maade, der formeentlig for Retten er muelig, nemlig efter Landets Love, ikke kunne medføre Sagens Afviisning, eller fortiden kunde komme under Paakjendelse.

Hvad dernæst den 3die Grund angaaer, formedelst hvilken Indstævnte formener, at nærværende Sag qvalificerer sig til Afviisning, nemlig: at det i Følge hans Embeds-Eed paaligger ham, af al Magt at bestride falsk Lærdom, og at han, for at have opfyldt denne formeentlige Pligt, ikke kan staae privat Mand, men alene Regieringen til Ansvar, da skjønnes det ikke, at hiin i Embedseden grundede Forpligtelse kan fortolkes 
derhen, at Præsten i Embeds-Medfør skulde have at bestride Meninger, der vare yttrede i trykte Skrifter, naar han antog, at der i disse indeholdtes nogen falsk Lærdom; thi foruden at der paa den Tid, PræsteEden blev foreskreven, formedelst Censuren ikke lettelig kunne udkomme noget Skrift her i Landet, som indeholdt Lærdom, der afveg fra den, Præsten efter Eed skulde haandthæve, og at det altsaa ikke er antageligt, at der ved hiin Forpligtelse til at bestride falsk Lærdom, skulde være sigtet til trykte Skrifter, saa ligger det og i Sagens Natur, at det ei kunde gjøres Medlemmerne af en saa talrig Stand til udvortes Kaldspligt, at optræde som Forfattere af Værker mod vrang Lærdom, men at Forpligtelsen til at bestride denne giennem Pressen, i alt Fald maatte være betinget af, at Vedkommende dertil følte Evne og indvortes Kald, hvoraf igjen følger, at Præsten ei kunde have at skylde Staten, men kun sin egen Samvittighed Regnskab for, hvorvidt han havde opfyldt denne Pligt, samt at han, naar han i Maaden, hvorpaa han i noget trykt Skrift bestred falsk Lærdom, fornærmede sine Medborgere, ei kunde undgaae at staae disse til Ansvar for Domstolene, ved at henskyde sig under sit Embedsansvar mod Staten.

Fremdeles viser og Lovens 2-17-22 hvorvidt den ene geistlige Embedsmand ved Kaldspligt er opfordret til at paatale den andens Lære, hvorimod Loven, udenfor den der angivne Vei, omhyggeligen søger at indskrænke enhver Præst til at virke i sin Menighed, overladende det $\mathrm{i}$ Almindelighed til de overordnede geistlige Embedsmænd, Provsterne og Biskopperne, at vaage over Religionsforedragets Reenhed, cfr. 2-16-1, 3 og 5 samt 2-17-1, 7 og 8; og endelig er det saameget mindre antageligt at den ommeldte, Præsterne i Følge deres Embedseed paaliggende Forpligtelse skulde omfatte Lærdom, der foredroges i trykte Skrifter, som Embedseden da, i aabenbar Strid med Symbolernes Øiemed, vilde indeholde Spiren til idelig Polemik om Kirkens Grundlærdomme.

Efter det Foranførte vil Indstævntes Afviisningspaastand ikke kunde gives Medhold; men da han for dette Tilfælde har forbeholdt sig Tilsvar i Sagens Realitet, vil denne eiheller fortiden kunne komme under Paakjendelse.

Thi eragtes: 
Den af Indstævnte, residerende Capellan ved Vor Frelsers Kirke paa Christianshavn, Hr. Nicolai Frederik Severin Grundtvig, nedlagte Paastand om nærværende Sags Afviisning, kan ikke gives Medhold. ${ }^{3}$

*

Det er let at se, at dommerne har snoet sig. De var havnet langt uden for det område, hvor de havde grund til at føle sig kompetente, men de skulle jo træffe en afgørelse, og mere eller mindre klart er de havnet $i$ den opfattelse, at den enkelte præst ikke af sin embedsed (præsteløftet) var forpligtet eller berettiget til at yppe strid om kirkens grundlærdomme, men at det - hvad Danske Lov kunne siges at støtte alene påhvilede provster og biskopper at våge over »Religionsforedragets Reenhed «. En præst havde intet ansvar uden for sit sogn, synes de at have ment - og heri kunne de som nævnt foran finde st $\varnothing t t e$ hos stiftsprovsten og biskoppen.

Vi ved ganske vist nu, at dette statskirkesyn stod for fald, og det er ikke uden interesse, at det i langt mindre grad prægede den endelige dom, der faldt et halvt år senere, men endnu bestod det.

Kendelsen fik altså den væsentlige virkning, at Grundtvig eventuelt også med andre medvirkende motiver - tog anledning af den til at søge sin afsked »saa jeg fra nu af, for Guds Ansigt, agter mig løst fra alle de Pligter og skildt ved alle de Rettigheder, Danmarks Love hidtil paalagde og hjemlede mig som lovlig kaldet og beskikket Lærer i den danske Kirke.« (Brev til biskop Münter, Breve nr. 297.)

Den borgerlige virkning af nedlæggelsen vedrørte selvfølgelig selve embedet som residerende kapellan ved Vor Frelsers Kirke, men Grundtvig opfattede selv nedlæggelsen som langt mere definitiv - noget de færreste synes at have bemærket. I brevet til biskoppen udtrykte han sig nemlig således: »...nedlægger jeg herved høitidelig i Haanden, hvorigiennem det er mig overantvordet, ikke alene det mig allernaadigst betroede Embede ... men i det Hele Lære-Embedet i den danske Kirke, saa jeg fra nu af ... « o.s.v.

At Grundtvig ikke fastholdt dette konsekvent, er der grund til at være taknemmelig for, men det viser, hvor dybt rystet han var over ved kendelsen tilsyneladende at blive forment retten til at følge sin kristelige samvittighed som præst.

Injuriesagen fortsatte og blev behandlet med stor grundighed. Fra Clausens meddelelse om, at han ville gå rettens vej (Adresseavisen, 10. 
september 1825), til den endelige dom den 30 . oktober 1826 gik der over et år. Selv om retsplejen var langsom, også i den slags sager, var det påfaldende længe. Det har ikke gjort det lettere for rettens medlemmer, at der udkom et stort antal skrifter om de spørgsmål, der var blevet rejst - sågar et biskoppeligt hyrdebrev - og at den prekære sag også blev omtalt fra byens prædikestole. Heller ikke de indlæg, der fremkom under selve sagsbehandlingen, var lette at tage stilling til - se f.eks. det lange indlæg fra H.N.Clausen, som efter hans død blev trykt i Mindre Arbejder, Kirkelige Forhold og Anliggender, København 1885. I den foreliggende sammenhæng er der hverken grund til eller plads til at gå nærmere ind på parternes argumentation, blot til at konstatere, at de talte forbi hinanden i usædvanlig grad. Clausen talte om videnskabelig frihed og ære, Grundtvig om retten til at bestride vranglære. Af betydning for sagens endelige udfald blev det nok, at Grundtvig udtrykte sig hedt og groft, mens Clausen var kold og formel. Dommerne kunne redde sig ved at bedømme det sprog, der var brugt, således som det fremgår af dommen.

Undervejs forsøgte Grundtvig endnu en gang at få sagen afvist, nu under henvisning til, at der var meddelt ham afsked i nåde - hvorved kongen formentlig skulle have givet udtryk for velvilje og anerkendelse. Det var ikke særlig kløgtigt og selvsagt resultatløst - hvorfor kan læses nedenfor.

Udskrift af Dom-Protocollen $i$

den kongelige Lands-Overret samt Hof-og Stads-Ret i Kjøbenhavn

Aar 1826 den 3ote October blev i Sagen:

Doctor og Professor Theologiæ Henrich Nicolai Clausen contra:

Forhenværende residerende Capellan ved Vor Frelsers

Kirke paa Christianshavn, Nicolai Frederik Severin

Grundtvig,

afsagt følgende:

D o m. 
Citanten Doctor og Professor Theologiæ Henrich Nicolai Clausen søger under nærværende Sag Indstævnte, forhenværende residerende Capellan ved Vor Frelsers Kirke paa Christianshavn, Nicolai Frederik Severin Grundtvig, for forskjellige formeentlig ugrundede og ærekrænkende Udladelser og Beskyldninger, som Sidstnæunte i et af ham i forrige Aar under Titel af: »Kirkens Gjenmæle mod Professor Theologiæ Dr. H.N.Clausen« udgivet Skrift, har fremført mod Citanten.

Den af Indstæunte fra først af gjorte Paastand om Sagens Afviisning, er ved Rettens Kjendelse af $10 \mathrm{de}$ April d. A. forkastet. Nu har Indstævnte vel efter den Tid paa ny nedlagt Paastand om Sagens Afviisning, grundet paa den ham, efterat hiin Kjendelse var afsagt, meddeelte Afskeed i Naade; men denne Paastand kan ikke komme i Betragtning, da Indstævnte ikke kan gives Medhold i, at Regieringen ved at medddele ham Afskeed i Naade, skulde have frikjendt ham for Ansvar med Hensyn til det Forhold, hvorfor han, under den aldeles private Sag imellem ham og Citanten, var sigtet.

Dette kan saameget mindre antages, da det, om han endog for sine Udladelser mod Citanten, var bleven anseet med Mulkt, ikke kunde være nogen Nødvendighed for ham, at han af den Aarsag skulde nedlægge sit Embede, og han altsaa, naar han desuagtet selv attraaede Afskeed, maatte kunne vente, at denne vilde blive ham meddeelt i Naade; thi kunde han saaledes, endog efterat Dommen i Sagen, paa foranførte Maade var gaaet ham imod, vente at erholde Afskeed i Naade, er man aldeles uberettiget til, af den Omstændighed, at Regieringen, under Sagens Gang, efter hans derom gjorte Ansøgning, har meddeelt ham en saadan Afskeed, at udlede, at Regieringen paa nogen Maade skulde have erkjendt ham uskyldig i det Forhold, som er Gjenstanden for Søgsmaalet imellem ham og Citanten.

Det her Anførte maa tillige medføre, at han heller ikke, som han subsidialiter har gjort, kan paaberaabe sig den foranførte Omstændighed, som nogen Friefindelsesgrund.

Forsaavidt Indstævnte iøvrigt har paaberaabt sig, at han, efter den af ham som geistlig Embedsmand aflagte Eed, var pligtig at bestride den Lærdom om religiøse Gjenstande, som han ansaae for vrang, bliver at 
mærke, at her ikke er Spørgsmaal om Indstæuntes Ret til at fremstaae som Modstander af den Lære, som Citanten i sit Skrift havde fremsat, hvortil Enhver, endog uden ved Embedseed at være paalagt saadant, maatte være berettiget; men at Spørgsmaalet alene gaaer ud paa, om han, ved at bestride Citantens Lærdomme, har betjent sig af utilbørlige og fornærmelige Udladelser mod denne, hvortil hans ovenanførte formeentlige Embedsforpligtelse ikke kunde give ham Bemyndigelse, og som han saameget mindre kunde være berettiget til, da Forordningen af 27de September 1799 § 5, (hvilket under Proceduren fra Indstævntes Side udtrykkeligen er indrømmet), maa antages at tillade frie Discussioner i trykte Skrifter, om religiøse Genstande, naar disse blot ikke gaae ud paa at nedbryde Læren om Guds Tilværelse og den menneskelige Sjels Udødelighed, og Forfatteren iøvrigt ikke tillader sig at laste eller forhaane den christelige Lære, hvilket Citanten aldeles ikke kan siges i det af ham udgivne Skrift, at have gjort, da han tvertimod høit anpriser berørte Lære.

Det kommer her ikke an paa at bestemme, hvorvidt de Læresætninger, som Citanten i sit videnskabelige Foredrag har fremsat, maatte kunne ansees for feilagtige, (hvilket ikke under denne Sag kan være at afgjøre), men Citanten maa kunne fordre, at naar han, i Overeensstemmelse med den Bemyndigelse, som det foranf $\varnothing$ rte Lovbud indeholder, foredrager de Sætninger, som han anseer for rigtige, og iøvrigt holder sig indenfor Grændserne af, hvad Forordningen har foreskrevet, maa Ingen, ved at bestride hans Læresætninger, angribe ham med utilbørlig og fornærmelig Tiltale.

At Indstævnte imidlertid ikke har fulgt denne Regel, fremlyser tilstrækkeligen af de af Citanten anførte forskjellige Steder i Indstævntes ovenanførte Skrift, hvor denne har tilladt sig de meest krænkende Yttringer om Citantens religiøse Foredrag, i det han endog siger om denne, at han i sin Bog har stillet sig i Spidsen for alle den christelige Kirkes Fiender og Guds Ords Foragtere i Landet, og at hans protestantiske Kirke er et Afgudstempel, samt betjener sig af forskjellige andre, ligesaa bittre Udladelser; og har han tillige paa flere Steder characteriseret Citantens Foredrag, som Vrævl og Daarekistesnak, m.v.

At hans Angreb, som han under Proceduren har yttret, alene skulde indeholde Sigtelse for, at Citantens Lære var stridende mod den christne 
Religion saaledes, som denne, efter de danske Love, skal foredrages her i Landet, kan ikke antages, da han paa forskjellige Steder i sit Skrift, saaledes i Fortalen pag. IV og VIII, og i Skriftet selv pag. 3 og 24, med flere Steder, udtrykker sig med en saadan Almindelighed, at derved maa være meent det hele christne Samfund fra dets første Oprindelse.

Men selv forsaavidt han bestrider Citanten med Hensyn til dennes Forklaring om, hvorledes de danske Loves Bestemmelser angaaende de i den danske Kirke gjeldende Symboler, efter hans Mening, ere at forstaae, har Indstævnte, efter det Foranførte, været uberettiget til at angribe Citanten paa den Maade, som skeet er; thi Citanten har ikke ved at fremsætte sine Anskuelser, nogensteds betjent sig af saadanne Udladelser, at han kan siges, enten at have lastet eller bespottet de nævnte Læresætninger, men han har alene søgt at oplyse, hvorledes han meente, at Symbolerne i den protestantiske Kirke, efter Protestantismens Aand, maatte anvendes.

At denne hans Lære skulde være af den Natur, at ethvert, med Hensyn til Udtrykkene, hvori det skede, for dens Forfatter nok saa krænkende Angreb derpaa, maatte ansees tilladeligt, vilde ogsaa staae $i$ en besynderlig Modsætning med, at den samme Lære i det Væsentlige, efter hvad der under Sagen er oplyst, ikke blot hyldes af Landets øverste, geistlige Embedsmænd; men endog udtrykkelig har været fremsat $i$ et af Rigets samtlige Biskopper til alle Landets Præster udstædt Hyrdebrev, der, førend dets Bekjendtgjørelse, har været forelagt Hans Majestæt, som derefter har tilladt, at det, saaledes som det var affattet, maatte uddeles blandt Geistligheden.

Retten maa, efter det Foranførte, ansee Citantens Paastand om, at de paaankede Udladelser mortificeres, og at Indstævnte for hans i den Henseende udviste Forhold ansees med Straf, for velgrundet.

Hensees imidlertid til, at der er Anledning til at antage, at Indstævntes Angreb paa Citanten ikkun hidrører fra Iver hos Indstævnte for det, som han anseer for det Rette, og at det ogsaa kan være troligt, at det, uagtet flere Udtryk i hans Bog synes at indeholde Angreb paa Citantens moralske Character, dog forholder sig, som han i den under Sagen fremlagte Erklæring fra ham, har opgivet, nemlig, at det ikke har været hans Tanke, enten at ville krænke Citantens borgerlige Ære, eller bedømme hans Sindelag og Hensigt; saa findes Straffen, naar disse 
Omstændigheder tages i Betragtning, passende at kunne, overeensstemmende med Forskrifterne i 6-21-4, og Forordningen af 27de September $1799 \S 12$ sidste Membrum, bestemmes til en Mulct af 100 Rigsbankdaler Sølv til Kjøbenhavns Fattigvæsens Hovedkasse. Saa bliver Indstævnte og at dømme til at betale til det Offentlige, Rettens Gebyhr, Skriversalarium og Omkostningerne til stemplet Papiir, forsaavidt disse Udgivter skulde været erlagte af Citanten, hvis Sagen ikke fra hans Side havde været beneficeret; ligesom han og bliver at tilpligte, at betale Citanten til Salarium til dennes Sagfører, 25 Rbdlr. Sølv.

Thi kjendes for Ret.

De af Citanten Doctor og Professor Theologiæ Henrich Nielsen (sic!) Clausen under nærværende Sag paaankede, af Indstævnte, forhenværende residerende Capellan ved Vor Frelsers Kirke paa Christianshavn, Nicolai Frederik Severin Grundtvig, i et af ham i Aaret 1825 udgivet Skrift, kaldet »Kirkens Gjenmæle mod Professor Theologiæ Dr. H.N.Clausen «, mod denne Sidste brugte fornærmelige Udladelser, b $\varnothing \mathbf{r}$ døde og magtesløse at være, og ikke komme Citanten til Skade paa nogen Maade; og bør Indstævnte for sit i denne Henseende udviste Forhold at bøde til Kjøbemhavns Fattigvæsens Hovedkasse, 100 Rbdlr. Sølv.

Saa betaler Indstævnte og til det Offentlige, Rettens Gebyhr, Skriversalarium og Omkostningerne til stemplet Papiir, forsaavidt disse Udgivter skulde været erlagte af Citanten, hvis Sagen ikke fra hans Side havde været benificeret. Endelig betaler han til Citanten, som Salarium til dennes Sagfører, 25 Rbdlr. Sølv.

Det Idømte udredes inden 15 Dage efter denne Doms lovlige Forkyndelse, under Adfærd efter Loven. ${ }^{4}$

Dommen standsede som bekendt ikke debatten - tværtimod. Den blev genoptaget af J.C.Lindberg med en bedømmelse af selve dommen i form af et skrift på mere end 80 sider og fortsatte i flere år, ikke mindst holdt vedlige af Lindberg, Gunni Busck og Rudelbach. Mange anså denne 
kirkekamp for at være af afgørende betydning. I et samlebind, der rummer en del af de mere væsentlige skrifter, har en desværre anonym ejer (at dømme bl.a. efter den gotiske skrifts form en præst i århundredets sidste fjerdedel) indklæbet følgende anbefaling:

Disse her samlede polemiske Skrifter fra Kirkekampens Tid tør ikke oversees som forældede Sager, man kan lægge hen - hvis man altsaa vil forstaae Grundtvigs og Lindbergs Færd dengang, og dømme retfærdig om Sagen, der har havt saa overordentlig Indflydelse paa senere Tider i christelig Henseende.

Clausen betragtede livet igennem denne fortsatte debat med stor bitterhed, og den løb egentlig også løbsk på mange måder. Den dom, som havde startet det hele, glemte man imidlertid snart, og den har vist aldrig været nærlæst med andre juridiske briller end N.M. Spandets. Han var medlem af retten, men tog offentligt afstand fra afgørelsen i et brev, som blev trykt i forordet til Lindbergs nævnte skrift. Det var imidlertid stærkt præget af, at han mente, at Grundtvig havde ret i sin kritik af Clausen, og dette svækkede selvsagt den juridiske argumentation.

Grundtvigs venner så dommen som et martyrium og glemte, at dette $\mathrm{i}$ hvert fald i visse henseender ikke var helt uforskyldt. Derimod betragtede Clausen den udadtil som en sejr - hans erindringer viser dog, at han ikke var helt tilfreds, og eftervirkningerne gav den også hurtigt karakter af en Pyrrhus-sejr. Begge parter - og mange efter dem - overså, at Grundtvig ikke - som Clausen havde krævet - var dømt for ærekrænkelser. (Selv Jørgen Larsen skrev på side 171 i sin disputats om Clausen fra 1945, at dommen »dømte Grundtvig som Æreskænder«.) Dommens henvisning til Danske Lov 6-21-4 gør det imidlertid helt klart, at Grundtvig blev dømt for »utilbørlige« ord, som netop ikke skulle betragtes som ærekrænkende. Dommens sidste afsnit om Grundtvigs motiver (»Iver hos Indstævnte for det, som han anseer for det Rette viser iøvrigt, at retten meget langt har accepteret Grundtvigs egen argumentation, hvad der også fik udtryk i den faktisk milde dom. Grundtvigs grove sprog havde gjort det umuligt at frikende ham, mente de dommere, der deltog i sagens behandling, men de fastsatte bøden til et meget lavt beløb, næsten så lavt som overhovedet hjemlet. At dommen havde den ulykkelige - og siden meget omtalte - virkning, at Grundtvig kom under censur, blev overhovedet ikke nævnt - det var som 
sagt ren automatik. Bøden og omkostningerne blev betalt af nogle af Grundtvigs venner.

Bortset fra, at Grundtvig nu stod uden embede - men den konsekvens havde han ikke behøvet at drage, mente dommerne - var en af de vigtigste følger, at han trak sig tilbage fra redaktionen af Theologisk Maanedsskrift, der blev videreført med Rudelbach som eneudgiver, dog stadig med Grundtvig som bidragyder.

Grundtvig deltog kun i begrænset grad i den fortsatte kirkekamp i de nærmeste år efter, at han havde udsendt det lille skrift med den mistrøstige titel »Skribenten Nik.Fred.Sev.Grundtvigs Literaire Testamente". Han overlod debatten til andre, hvoriblandt J.C.Lindberg som nævnt var den ivrigste og voldsomste. Det forekommer mig ikke oplyst, om Lindbergs aktivitet blev støttet helhjertet af Grundtvig, uanset at mange i samtiden misforstået så dem som to alen af et stykke. (Der skulle imidlertid meget til, for at Grundtvig offentligt tog afstand fra sine venner. Han var i virkeligheden ganske kritisk mod mange af dem, men forblev altså sine venners ven.) I den næste fase af kirkekampen, der begyndte 1831-32, deltog Grundtvig med iver, men den havde ingen umiddelbar forbindelse med røret om »Kirkens Gjenmale».

Forholdet mellem Clausen og Grundtvig er ofte fremstillet meget firkantet. Man kan se dem omtalt som »fjender «, også når det gælder langt senere perioder. Det er alt andet end korrekt. De blev aldrig enige, endsige venner, men de lærte at påskønne nogle positive træk hos hinanden, og i det lille Danske Samfund måtte to så fremtrædende liberale personligheder på trods af deres forskelle ofte komme til at støtte hinanden - f.eks. ved skandinaviske initiativer, på det sønderjydske område, i arbejdet for Rødding højskole, ja selv med hensyn til visse kirkelige anliggender.

Mest sigende er måske forløbet af Præst $\varnothing$-valget til den grundlovgivende rigsforsamling. Clausen havde tidligere repræsenteret området i stænderforsamlingen i Roskilde, og nu ville nogle i kredsen opstille ham. Andre henvendte sig til Grundtvig, men han sagde nej - »da Clausen var indbudt fra Præst $\varnothing$, trak jeg mig tilbage før han selv bad mig derom« skrev Grundtvig til sønnen Johan den 2. september 1848. Det kan læses, som om Clausen faktisk havde været hos ham og bedt ham om at holde 
sig borte, men det var næppe tilfældet. Tværtimod skrev P.O.Boisen den 7. september til sin svoger Svend Grundtvig:

„Clausen var hos Din Fader forleden for at tilbyde ham at træde tilbage for ham i Præstøe, som han dog ikke vilde tage imod.«

Baggrunden var nok, at Clausen frygtede for, at valget ville falde på bomuldsvæver Hans Hansen, medmindre Grundtvig stillede op i Clausens sted, og sådan gik det jo også. Men Peter Rørdam, Grundtvigs gode ven og senere svoger, var en af Clausens anbefalende stillere, som han senere var en af Grundtvigs. Alt dette giver indtryk af en gensidig agtelse, der dårligt kan tænkes forenet med egentligt fjendskab.

Med tiden kom såvel Grundtvig som Clausen også til at se på modsætningen fra 1825-26 med andre øjne.

Allerede i 1839 skrev Grundtvig i »Aabent Vennebrev til en engelsk Prast « (side 9): »Jeg vil saameget mindre oprippe Stridighederne med Prof. Clausen, som jeg, med min nuværende Indsigt, enten vilde undgaaet dem, eller ført dem ganske anderledes... «Og i »Kirke-Speil«, foredrag holdt 1861-63, trykt 1871, står der (side 379f.), at »det saakaldte »Kirkens Gienmæle« med Pen og Blæk imidlertid nu staaer for mine Øine som et urimeligt Luftspring og et fortvivlet Vovestykke...«

Clausen ventede med en tilsvarende indrømmelse til erindringerne „Optegnelser af mit Levneds og min Tids Historie«, der blev udgivet posthumt i 1877. Her kan man side 125f. om den oprindelige bog fra 1825 læse, at han nu er »fuldkommen villig til at erkjende, at der er Partier i Bogen, som have et noget ungdommeligt Præg «. Hvis bogen skulle komme i en ny udgave, burde man lægge den tyske udgave til grund, fordi den var »Resultat af et fuldstændigt og omhyggeligt Gjennemsyn «. Noget floromvundet fik Clausen også sagt, at den kritiske hjælp først og fremmest var kommet fra hans modstandere, så han kunne »vende til det Gode, hvad der har været ment ondt.«

Der var ikke så lidt bitterhed tilbage hos Clausen, da han skrev erindringerne, men den var først og fremmest rettet mod folk som Lindberg - og hvad der er væsentligt til belysning af situationen også i 
1826 - mod de personer inden for kirken, som han syntes havde svigtet ham i kampen. Blandt dem var den vigtigste - og den, der levede længst - J.P.Mynster, som kun privat, men aldrig offentligt havde givet udtryk for en vis sympati. Netop i 1826 blev Mynster, der var biskop Münters svigersøn, hofprædikant, og måske ville han ikke bringe sin stilling $\mathrm{i}$ fare ved ensidigt at gå imod Grundtvig, men han var også livet igennem på mange måder uenig med Clausen, som han måtte anse som en farlig konkurrent, selv efter at han i 1834 var blevet Sjællands biskop. De to var gennem en årrække de mest fremtrædende kirkepolitikere og trak sjældent på samme hammel.

Så vidt som det var dem muligt, holdt både Clausen og Grundtvig sig borte fra den fortsatte kirkekamp. Kirkens Gjenmaele blev ikke genoptrykt efter 1825 - først i 1877, da stridens hovedpersoner begge var døde - , og den af censuren forbudte (men allerede trykte) tredje del af afhandlingen »Om Religions-Frihed « fra 1827 blev først udgivet i 1866. På sin side undlod Clausen at offentliggøre sit partsindlæg fra retssagen - det blev som nævnt foran først trykt i 1885. Denne undladelse havde iøvrigt den virkning, at Lindbergs og andres let hoverende påstande om, at dommen havde mortificeret nogle udtryk uden at specificere disse, stod uimodsagt $i$ en lang årrække og måske stadig tages for gode varer af nogle. Hvis man vil vide, hvilke udtryk det var, som dommen mortificerede, kan man finde dem i Clausens indlæg. Det fremgår af præmissernes ord om »de paaankede Udladelser «. Måske mente retten, at den ikke burde give vendingerne større udbredelse, og det kan man give den ret $\mathrm{i}$ - heller ikke for os kan de have større interesse.

Retssagens enkeltheder gik hurtigt i glemmebogen. Kun myterne om den og om Grundtvigs hele martyrium blev tilbage.

Det skal her navnes, at man også i andre varker kan finde redegфrelser for, at der blev pålagt Grundtvig censur som en følge af dommen, således hos H.J. Glademark, N.F.S. Grundtvigs nedlaggelse af Prasteembedet $i 1826$. Kirkehistoriske Samlinger, Sjette Rakke, Tredie Bind, Kobenhavn 1939-42, s. 201ff; Grethe Bфje, Injuriesagen mod Grundtvig 1825-1826, Grundtvig-Studier 1984, s. 34ff. og Jørgen Glenthøj, Injurieprocessen mod Grundtvig 1825-26, I. N.F.S. Grundtvig - Theolog og kirkelarer, Kbh. 1983, s. 77ff. 
1 Det er bemærkelsesværdigt, at Grundtvig husker galt: Dommen faldt i 1826, og han havde været under censur i fulde elleve år - det første "Imprimatur" er dateret 20. december 1826 - det sidste "Maa trykkes" står foran i sangværket, der forelå som færdig bog i september 1837 og var det sidste, som Grundtvig udsendte før nytår 1838. Som også andet tyder på, synes Grundtvig at have lagt det bitre minde om dommen bag sig forholdsvis hurtigt. Ellers havde han næppe fået uorden i kronologien. Senere tider har ikke fået lov at glemme årstallet 1826.

2 Gengivelsen er bogstavret, uanset at der åbenbart kan være enkelte trykfejl i Roeds tekst. Steen Johansen, der ved bibliografiens nr. 443 omtaler den lille tryksag, har ikke identificeret Roed, og jeg har heller ikke kunnet spore ham. At det skulle være maleren Jørgen Roed, der på dette tidspunkt kun var atten år, er nok en for dristig formodning, men han tilhørte dog en kreds, der i det mindste for en lidt senere periodes vedkommende er kendt for sin kontakt med Grundtvig. Når jeg har brugt hæftets tekst og ikke eftersøgt de originale dokumenter i arkiverne, skyldes det $\emptyset$ nsket om at præsentere materialet $\mathrm{i}$ den form, hvori datidens offentlighed fik kendskab til det.

Danske Lov 2-17-22:Alle Geistlige Personer, som Superintendenterne have under sig, skulle ære deris Superintendent, og lyde hannem i de Ærinder, som een Superintendent befalede ere, under deris Embedis Forbrydelse; Men finde de med hannem nogen merkelig Last, eller hand fører nogen vrang Lærdom, eller forsømmer sit Embede, saa at hans Brøst er saa stor, at hand ikke enten kand, eller vil, raade Bod derpaa, da skulle hverken Præsterne, eller de andre Superintendenter tie med hannem; Men give Kongens Stigtsbefalningsmand det tilkiende, som det for Kongen $b \varnothing r$ at andrage. Ellers maa Kongens Befalningsmænd ingen Superintendent for Kongen beføre, naar hand ikke er aabenbare berøgtet; Men de skulle Superintendenterne beskierme og forsvare, om Behov giøris.

Danske Lov 2-16-1, 2-16-3 og 2-16-5:

Der skal være een Provst i hvert Herret, som skal være Superintendentens Medhielper at tilholde Kirke- og Skole-Tienere at giøre deris Embede, og see til, at alting gaar allevegne skikkelig og ret til. [fortsættes]

Provsterne skulle eengang $\mathrm{i}$ det ringeste, eller oftere, om Aaret, om Superintendenten det nødigt eragter, besøge alle Sognene i deris Provstj, i hvo de og tilhøre, og jus Patronatus til dennem have, og forhøre, hvorledis Præsten prædiker, udlegger Børnelærdommen, uddeleer Sacramenterne, og om de i alle maader sømmelig staa deris Embede for, og pryde det med et got Levnet.

Dersom de befinde nogen Brøst, eller Forsømmelse, hos Præsterne, eller andre deris underhavende Geistlige, i deris Embede, Forhold og Levnet, da skulde de flittelig paaminde dem hvad de bør at giøre, og hvilke sig da ikke ville rette, dennem skulle de indføre for Superintendenten, og hvilke hand da ikke kand sette 
til Rette, dennem skulle de stævne til Provstemode for Kongens Stigtsbefalningsmand og Superintendenten, og aldelis intet Uskikkeligt dølle, eller underslaa, men tilbørligen lade det paatale og straffe, saa fremt de ikke selv derfor ville stande til Rette.

Danske Lov 2-17-1, 2-17-7 og 2-17-8:

I hvert Stigt skal være een Superintendent, som Kongen dertil beskikker og stadfæster, som skal have alle Provster, Præster, Skoletienere, Dægne og Substituter, under sig, og holde dem til at giøre deris Embede, og see til, at alting gaar skikkeligen og ret til, som her befalis.

De skulle legge Vind paa, at alle Præsterne retsindeligen og eendrægteligen lære Christi hellige Evangelium, og andet der bør at følge med, og at Præsterne med deris Hussinde føre et skikkeligt Levnet, saa som saadanne Christi Tienere vel anstaar.

Men hvilke, som derimod giøre, og ikke tage Vare paa deris Embede, eller leve Uskikkeligen, dennem skulle de give Paamindelse og Advarsel, og straffe dem, saa at de enten bedre sig, eller lade dem for Kongens Stiftsbefalningsmand og sig i Provstemodet indkomme, og sette dem af deris Embede.

Danske Lov 6-21-4:

Ere Ordene ikke nogens Ære og Lempe for nær, og dog kiendis af Dommeren at være Utilbørlige, da maa de med Pengestraf forsonis, efter som de ere grove til; Og skal ingen Æredom udstedis for Ord, som Ære og Lempe ikke vedkomme, og ved hvilke ingen sigtis paa ærlig Navn og Røgte. If $ø$ lge trykkefrihedsforordningens $\S$ 12 var strafferammen bøde fra 50 til 1000 rigsdaler - for ærekrænkelse tugthus. Det ikke længere brugte juridiske udtryk »under adfærd efter loven « betyder ifølge ODS, at dommen kan gennemføres ved tvang, især ved udlæg i den dømtes ejendele, hvis den ikke efterkommes. 